\title{
Tropical rainforest palm communities in Madre de Dios in Amazonian Peru
}

\section{Comunidades de palmas en los bosques tropicales de Madre de Dios de la Amazonía Peruana}

\author{
Henrik Balslev *1, Per Laumark ${ }^{1}$, Dennis Pedersen ${ }^{1}$ and Cesar Grández ${ }^{2}$ \\ 1 Ecoinformatics and Biodiversity, Biosciences, Aarhus University, Build. 1540, Ny Munkegade114, DK-8000 Aarhus C., Denmark. \\ 2 Facultad de Ciencias Biológicas, Universidad Nacional de la Amazonía Peruana (UNAP), Iquitos, Perú. \\ * Corresponding author \\ Email Henrik Balslev: henrik.balslev@bios.au.dk \\ Email Dennis Pedersen:dennis.pedersen@bios.au.dk \\ Email Cesar Grández: cgrandezii@hotmail.com
}

\begin{abstract}
We studied palm communities, in particular species-richness and abundance, in the tropical rainforests in southeastern Peru in 54 transects $(5 \times 500 \mathrm{~m})$ covering an area of 13.5 hectares in flood plain, terra firme, terrace and premontane hills. We found 42 palm species in 18 genera in the transects. Terra firme forest had the highest species richness (38 species) followed by floodplain and premontane hills with 27 species and terrace forests with 26 species. The highest palm abundances were found in premontane hill forest which had 3243 palms per hectare and terra firme forest which had 2968 palms per hectare. The floodplain forests were intermediate in palm abundance with 2647 and the terrace forests had the lowest abundance with 1709 palms per hectare. Intermediate sized palms were the most common being represented by 18 species, while large palms were represented with 16 species. There were only eight species of small palms of which one was acaulescent. Only one species of liana palm was registered. Of the 42 species observed in the 54 transects, 20 were cespitose, 21 solitary and two had colonial growth. Seven species were found $40-320 \mathrm{~km}$ outside of their previously known range.
\end{abstract}

Keywords: Abundance of palms; Arecaceae; species richness; growth form; community structure.

\section{Resumen}

Estudiamos las comunidades de palmas de los bosques pluviales tropicales del sur de Perú, con especial énfasis en su riqueza de especies y abundancia, utilizando 54 transectas $(5 \times 500 \mathrm{~m})$, que cubrieron un área de 13.5 hectáreas en planicie inundable, terra firme, terraza y colinas premontanas. Encontramos 42 especies de palmas en las transectas. En el bosque de terra firme se encontró la mayor riqueza de especies (38 especies), seguido por la planicie inundable y las colinas premontanas con 27 especies y los bosques de terraza con 26 especies. Las mayores abundancias se encontraron en el bosque de colinas premontanas, con 3243 palmas por hectárea, y en el bosque de terra firme con 2968 palmas por hectárea. Los bosques de la planicie inundable presentaron una abundancia intermedia con 2647 palmas por hectárea y los bosques de terraza presentaron la menor abundancia con 1709. Las palmas de tamaño intermedio fueron las más comunes, estando representadas por 18 especies, mientras que las palmas grandes estuvieron representadas por 16 especies. Se encontraron solamente ocho especies de palmas pequeñas, una de las cuales era acaulescente. Sólo se registró una especie de palma trepadora. De las 42 especies observadas en las 54 transectas, 20 fueron cespitosas, 21 solitarias y dos presentaron crecimiento colonial. Siete especies se encontraron 40-320 $\mathrm{km}$ fuera del rango de distribución conocido previamente.

Palabras clave: Abundancia de palmas; Arecaceae; riqueza de especies; forma de crecimiento; estructura de comunidad.

Citation:

Balslev H., P. Laumark, D. Pedersen and C. Grández. 2016. Tropical rainforest palm communities in Madre de Dios in Amazonian Peru. Revista peruana de biología 23(1): 003 - 012 (Abril 2016). doi: http://dx.doi. org/10.15381/rpb.v23i1.11828

Presentado: $\quad$ 07/03/2016

Aceptado: $\quad 17 / 04 / 2016$

Publicado online: $28 / 05 / 2016$
About the authors: HB and CG conceived and designed the study, all authors participated in fieldwork, HB and PL wrote the manuscript, all authors approved the final manuscript. Authors declare no conflicts of interest.

Funding: This work was supported by the Danish Council for Independent Research - Natural Sciences [grant\#4181-00158 to HB] and the European Community [FP7 grant \#212631 to HB]. 


\section{Introduction}

The palm family (Arecaceae) has 182 currently accepted genera with around 2600 species, most of which are restricted to tropical and subtropical climates (Dransfield et al. 2008; Baker \& Dransfield 2016). Palms are abundant throughout the tropics, and thrive in almost every possible habitat, but their diversity is highest in wet, lowland rainforests. The vast Amazon basin houses 151 species of palms (Henderson 1995). Colombia's 247 native palms (Galeano \& Bernal 2010) may be the highest number of palm species in any tropical American country, whereas Peru counts 149 species (Balslev et al. 2015). Palms inhabit a variety of ecosystems in tropical America. More than two thirds of palm species live in tropical forests, where some grow tall enough to form part of the canopy and shorter ones form part of the mid- and understories (Balslev et al. 2011). Some species form pure stands, usually in areas with poor drainage or regular flooding. In the Amazon basin the most common and widespread of these palms that form monodominant stands is Mauritia flexuosa L.f. that is very abundant in swamps, particularly in the western parts of the Amazon basin. Other palms live in tropical mountain habitats up to 3000 meters above sea level, such as species in the genus Ceroxylon which are all native to the Andes (Sanín \& Galeano 2011). Palms also inhabit grasslands and scrublands, and are then usually associated with a water source, sometimes under periodical flooding, such as Copernicia alba Morong ex Morong $\&$ Britton, which is common in seasonally flooded savannas in northern Argentina, Paraguay, southwestern Brazil and central and southern Bolivia (Moraes 2004).

The edible fruits of palms make them keystone species for the survival of many animals living in the tropics (Peres 1994, Kinnaird 1992). Palms are also used by humans and provide a variety of products such as oil, palm heart, building materials and material for basketry (Balslev 2011). A few species like Mauritia flexuosa and Oenocarpus bataua Mart. even have the potential to be economically important for large scale export activities (Brokamp et al. 2011, Kahn 1988). In order to use this potential of the palms in the most sustainable way, it is necessary to know more than just the distribution of each species.

The palm communities of the Madre de Dios region in Peru are essentially unknown and their composition and structure remains to be documented. Kahn and Moussa (1994) assessed the diversity and conservation status of palms in Peru (including Madre de Dios) and reported 140 species in 34 genera for the entire country. About $43 \%$ of the species occurred at very low or low frequencies and about $9 \%$ were insufficiently known in situ for their conservation status to be defined. This is yet another reason for more in-depth studies of the palm communities in Peru. Other than Kahn and Moussa's study of Peruvian palms and Henderson's treatment of the palms of the entire Amazon basin (Henderson 1995), no palm studies have included the Madre de Dios region. Our study provides insight on how common or rare the palm species are in that region, and about how they are grouped in communities, which species occur together, how many species occur in different habitats, and how the different life forms are represented in different habitats. This information allows us to update and complement our knowledge about the distribution of the Peruvian palm flora. This contribution, in addition to providing new information and exploring the nature that surrounds us, is important for conservation and sustainable management of the palms in the Madre de Dios region and elsewhere.

\section{Study area}

Peru houses many different vegetation types that are assembled in complex ecological environments. These are shaped by large variations in both altitude and rainfall. Here, we focus on the Madre de Dios region in eastern Peru (Fig. 1). The study area is located in lowland tropical forest at altitudes between 100 $-500 \mathrm{~m}$. The climate is warm and damp, with average temperatures around $26^{\circ} \mathrm{C}$ (variation $21-34^{\circ} \mathrm{C}$ ). The rainy season is from December to March, when torrential rainfall causes rivers to swell and often overflow their banks. Annual precipitation can be as much as $3000 \mathrm{~mm}$ (Cochrane \& Cochrane 2011).

The great extent of Amazonian forests, together with the regional peculiarities of the soil types and river systems within the basin, allows for a number of very distinctive forest types to exist, each with its own specialized flora. These forest types are recognized in many publications, but here described based on our experience from making close to 600 transects in the western Amazon basin from Colombia to Bolivia and also in the Brazilian state of Acre.

By far the largest area is taken up by terra firme forest, which is the 'standard' forest type that one usually has in mind when referring to the Amazon rainforest. Terra firme forest occupies well-drained soils that are relatively poor in available nutrients. The dense forest canopy reaches $40 \mathrm{~m}$ height and is usually very rich in tree species, while the interior is relatively dark and open.

The floodplain is the area along the rivers that is inundated when the water level in the river rises. It is flat land and the soils are alluvial (sand, silt, and clay) deposited during floods. Usually, the river winds its way through the floodplain, forming loops, a process known as meandering and braiding, where the water erodes the landscape on the outside of the turn and deposit material into the inside of the turn. In this way, the river erodes its way through the floodplain and can move several hundred meters per year (Salo et al. 1986). Because of this river dynamics, the floodplain forest is usually not as old as the other types of forest.

The terraces are adjacent and similar to floodplains, also lying along the river, but outside the flooding zone. Terraces are flat and originated as floodplains, but have been raised higher due to tectonic movements. Consequently, they are no longer subjected to river erosion and the forest is therefore generally older and taller than the floodplain forest.

Premontane hills are the outer slopes of the transition between a plain and a mountain range formed by uplifting. The soils there are loamy and often rich in nutrients. Like the flat plains below, the hills are covered with dense, tall broadleaf forest with a high diversity of trees, shrubs, epiphytes, herbs and also some lianas.

Our transects were surveyed in three different areas of the Madre de Dios region (Fig. 1). The first area was located 5-40 km south of the town of Iñapari, about $200 \mathrm{~km}$ north of the Madre de Dios river, and included exclusively terra firme forests. The second area was located around the town of Puerto Maldonado (ca. $100 \mathrm{~km}$ west to $60 \mathrm{~km}$ east) and included mainly surveys on floodplains, but also some on terra firme forests. The third area was at s slightly higher altitude and located some $150 \mathrm{~km}$ west 

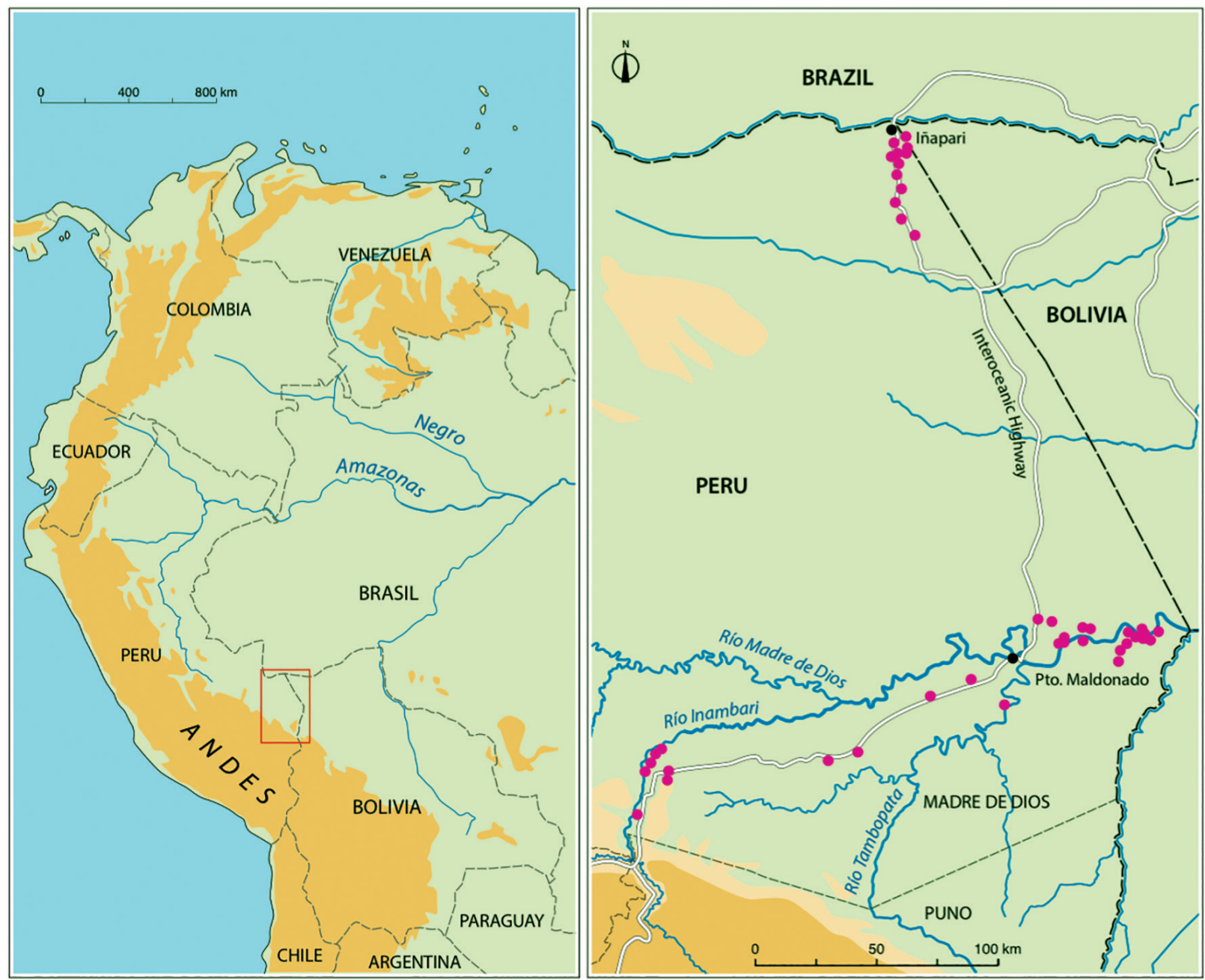

Figure 1. Map of the tri-state region between Peru, Brazil and Bolivia showing the Madre de Dios region with location of $545 \times 500 \mathrm{~m}$ transects (red dots).

of Puerto Maldonado, near the Inambari river, and included mainly terrace and premontane hill forest (with some additional terra firme forest transects).

\section{Methods}

We visited the Madre de Dios region during February-April 2011 to explore its palm flora and palm communities with the objective to determine the abundance of palm species in different habitats.

We surveyed 54 transects of $5 \times 500 \mathrm{~m}$. Each transect was divided into hundred $5 \times 5 \mathrm{~m}$ subunits, in which we identified all palm species and counted the number of individuals, noting if they were seedlings, juveniles, subadults or adults. Seedlings were the very young plants with their first seedling leaves; juveniles were young plant that had not reached the mature size; subadults were palms that had reached the size of reproductive individuals but did not show any sign of having reproduced; and adults were plants that showed signs of having reproduced or actually had reproductive structures. The transects were laid out so that they would represent the variation in vegetation as recognized on satellite images. After selecting a site we would approach its position as closely as we could on the Madre de Dios river or by road, and then walk to the site guided by a GPS. Once at the site, we cut a straight trail, avoiding damage to the palms along the trail, and placed sticks every five meters, marking each stick with a pre-printed paper label with the transect number and subunit number.

We collected 123 herbarium specimens that are deposited in the Herbarium Amazonense (AMAZ) of the Universidad Nacional de la Amazonia Peruana in Iquitos (Peru) and at Aarhus University (AAU, Denmark). We collected and took pictures of most of the species including specimens of seedlings, juveniles and adults. A few palms that were common and well documented were not collected. Detailed collection data and photos of each of the 123 specimens are uploaded on the Aarhus University Herbarium webpage and can be viewed at www.au.bot.dk (enter collector "Balslev" and number range "8349-8471").

\section{Results}

Palm species.- In total we counted and identified 37181 individuals. These represented 42 species and 18 genera of palms in the 54 transects in the Madre de Dios region (Table 1). Seven of the observed species were collected beyond their previously reported ranges (Bjorholm et al. 2005, Henderson et al. 1995). The largest range extensions were for Geonoma maxima var. chelidonura (Spruce) A.J. Hend. and Bactris hirta var. spruceana (Trail) A.J. Hend. which were found $320 \mathrm{~km}$ and $250 \mathrm{~km}$, respectively, beyond their previously known ranges, and Chamaedorea angustisecta Burret, Chelyocarpus ulei Dammer, Geonoma laxiflora Mart., Socratea salazarii H.E. Moore and 
Table 1. The Madre de Dios region's palm community with indication of name, collecting number, number of individuals encountered in $545 \times 500 \mathrm{~m}$ transects (total 13.5 hectares), and the average number of individuals/species in each of four habitat types (terra firme, floodplain, terrace and premontane hills). The growth form of each species is indicated as LaT (=large tree), MsT (=medium sized tree), Shr (=shrub), Aca (=acaulescent), Lia (=liana), and the palm architecture is given as Col (=colonial), Sol (=solitary), Ces (=cespitose), and the leaf form is given as pal (=palmate), pin (=pinnate) and cop (=costapalmate).

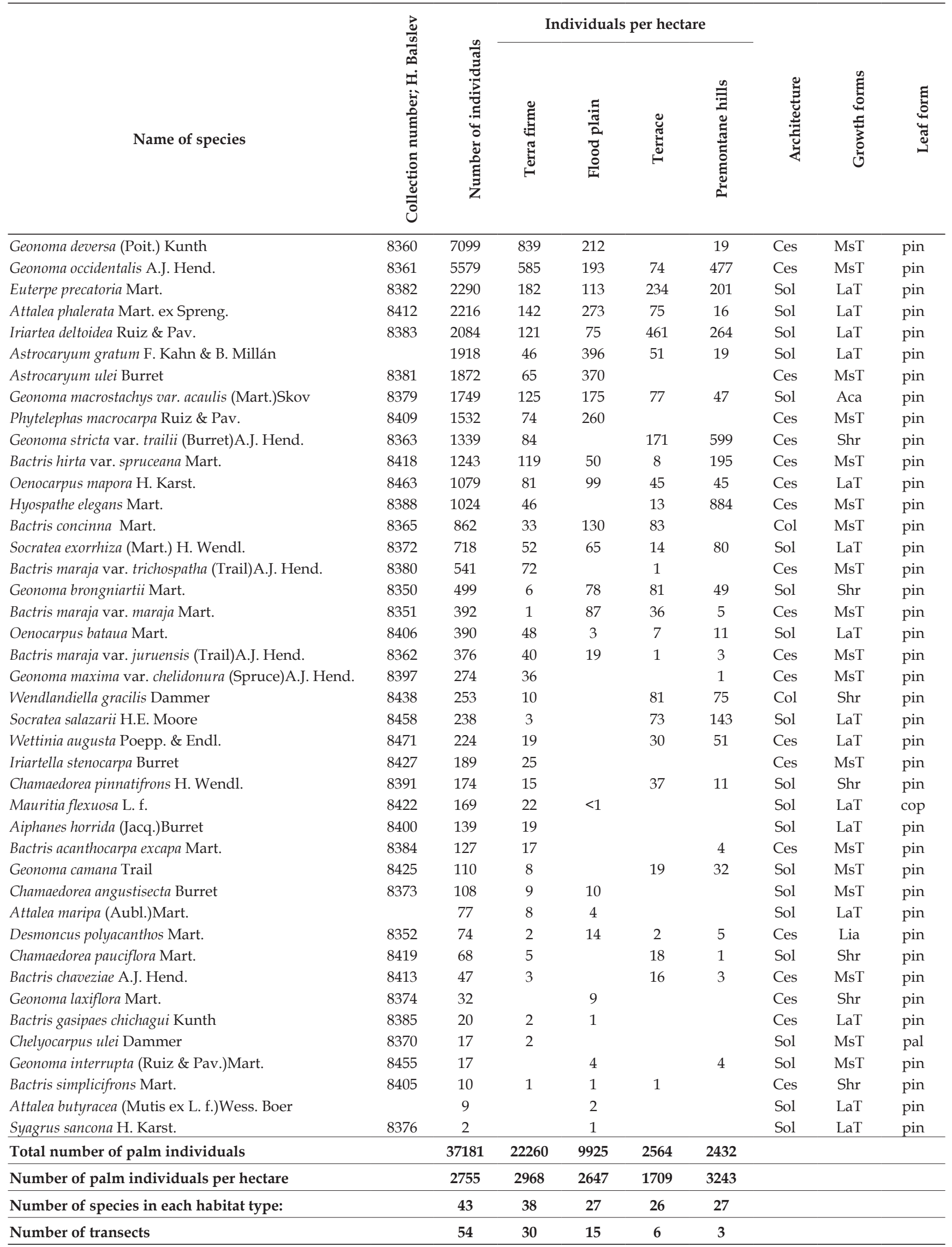




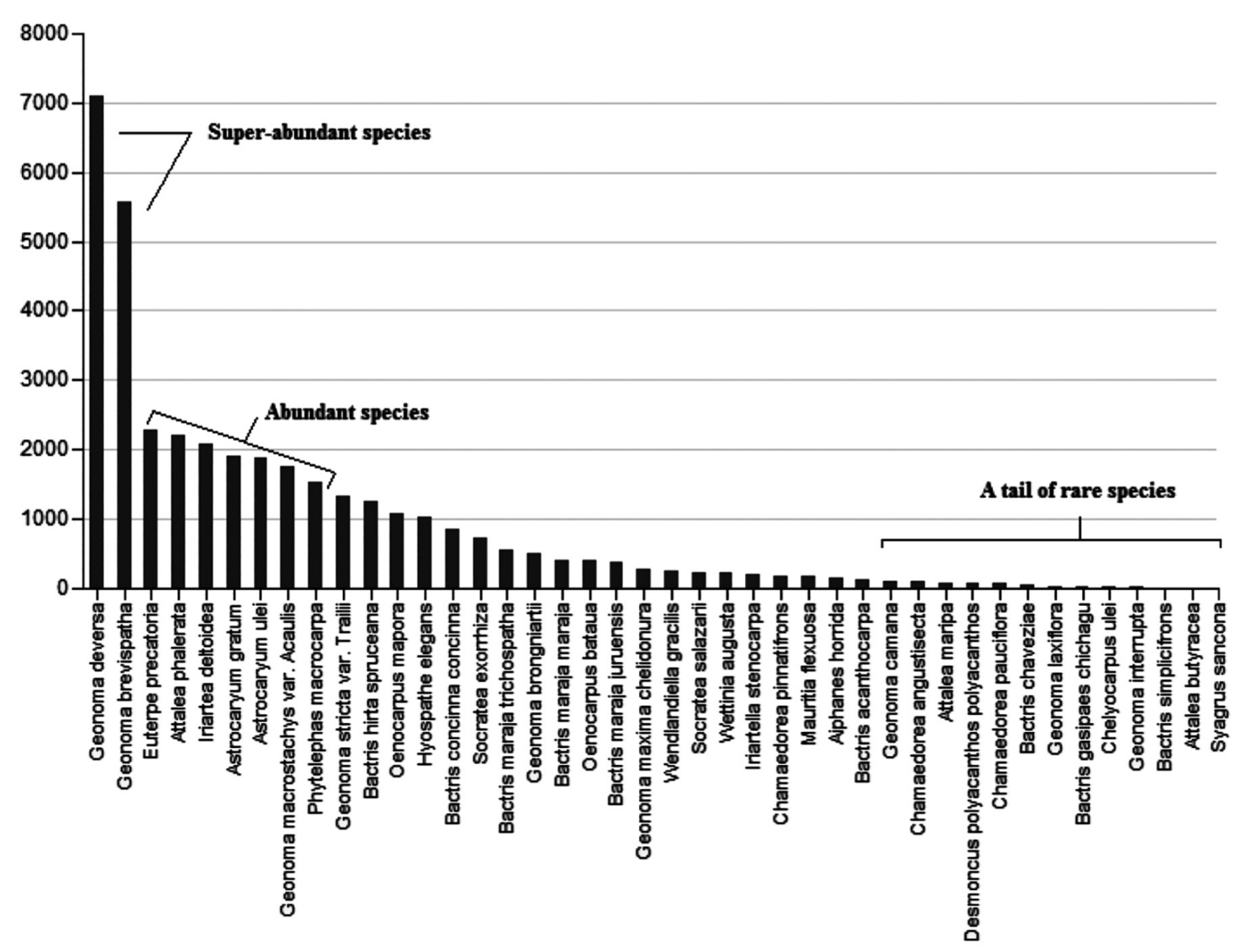

Figure 2. The abundance of palm species in 54 transects in the Madre de Dios region of Peru.

Wettinia augusta Poepp. \& Endl. which were found 40 - 160 $\mathrm{km}$ beyond their previously known ranges. Cocos nucifera L. was observed in two transect but disregarded since it is an introduced species that had invaded the forest near the river.

Palm communities.- Each habitat (floodplain, terra firme, terrace, premontane hill) had its own species composition, suite of dominant species and palms density values (Table 1).

In the terra firme forest (30 transects) we found a density of 2968 individuals per hectare and 38 palm species, the highest in any of the habitats. Geonoma deversa (Poit.) Kunth and $G$. occidentalis (A.J.Hend.) A.J.Hend. were the most abundant species and at least three times as abundant as any of the other palm species in this forest. Iriartella stenocarpa Burret, Aiphanes horrida (Jacq.)Burret and Chelyocarpus ulei Dammer were only registered in terra firme forests. In the floodplain forests (15 transects) we found a density of 2647 palm individuals per hectare and 27 species. Astrocaryum gratum F. Kahn \& B. Millan and Astrocaryum ulei Burret had the highest abundances. Three species were exclusive to these forests: Geonoma laxiflora Mart., Attalea butyracea (Mutis ex L.f.)Wess. Boer and Syagrus sancona $\mathrm{H}$. Karst. In the terrace forest ( 6 transects) we found a density of 1709 palm individuals per hectare and 26 species, which were the lowest density and species richness values found in any of the habitats. Iriartea deltoidea Ruiz \& Pav. was the most domi- nant species in the terrace forest, followed by Euterpe precatoria Mart. and Geonoma stricta var. trailii (Burret) A.J.Hend, with no species exclusive to it. The premontane hill forest ( 3 transects) had a density of 3243 palm individuals per hectare, which was the highest palm density registered. The premontane hill forest contained 27 species, of which Hyospathe elegans Mart. was the most abundant species followed by $G$. stricta var. trailii and $G$. occidentalis. No species was restricted to the premontane hill forest.

Abundance.- Overall, Geonoma deversa (Poit.)Kunth and $G$. occidentalis were the two most abundant (super-abundant) palms with more than twice as many individuals as any of the other palm species (Table 1, Fig. 2). Some of the more common and abundant species included Euterpe precatoria, Attalea phalerata Mart. ex Spreng., Iriartea deltoidea, Astrocaryum gratum and Astrocaryum ulei. In contrast, species like Geonoma interrupta, Bactris simplicifrons, Attalea butyracea and Syagrus sancona were rare in this region of the Madre de Dios (Table 1, Fig. 2).

Palm architecture and growth forms.- Intermediate sized and large palms were the most common, being represented by 18 and 16 species, respectively. There were only eight species of small palms in the sample and one of them was acaulescent. We found only one species of liana palm (Table 1, Fig. 4). Out of the 18 intermediate sized palms four were solitary, one 


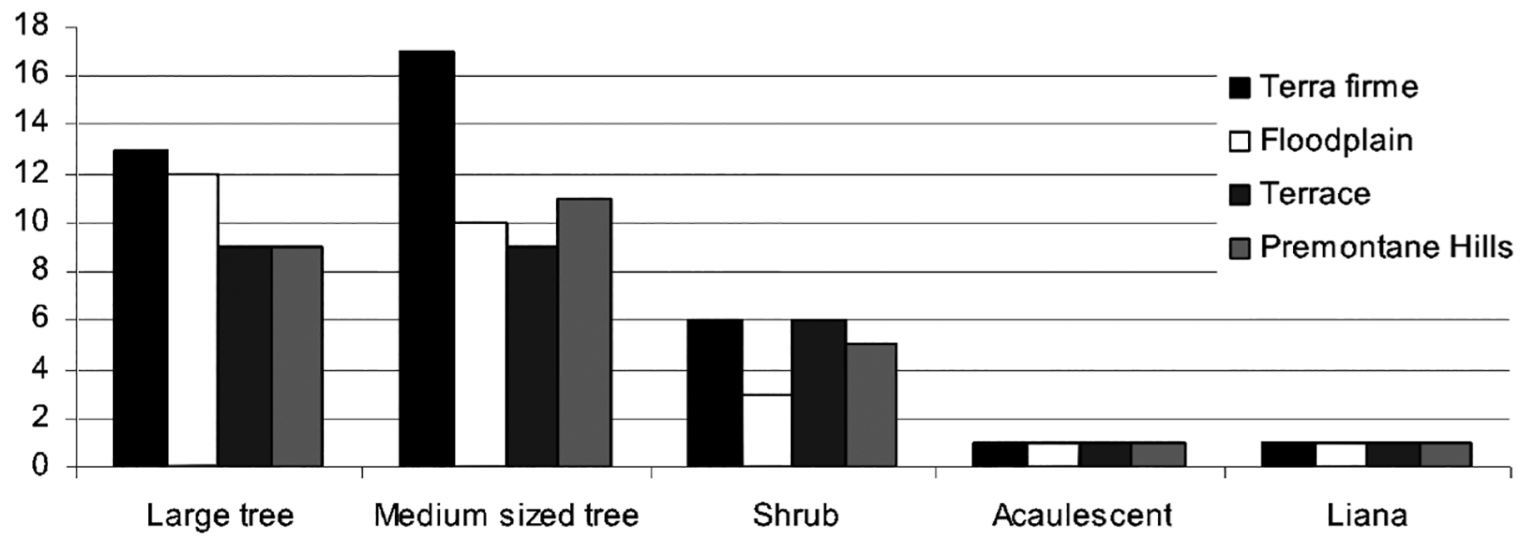

Figure 3. Number of palm species in each growth form and each habitat in 54 transects in the Madre de Dios region of Peru, divided by four different habitats of five growth forms.

colonial and 13 were cespitose. Of the eight small palms half were solitary, one colonial and three cespitose. None of the large palms were colonial, 13 were solitary and three were cespitose (Table 1, Fig. 4).

Growth forms and habit type.- All five growth forms (large, intermediate, small, acaulescent and liana) were present in each of the four habitats studied (Table 1, Fig 3). There was only one acaulescent (Geonoma macrostachys var. acaulis) and one liana (Desmoncus polyacanthos) species, both present in all habitats. Terra firme and premontane hill forest were both represented by more medium sized palms than large and small palms. Small palms were the least represented growth form with only 5-6 species. We found more species in terra firme forest, than in any other habitat, mainly because of the high number of medium sized palms there (Table 1, Fig. 3). The floodplain forest had more large palms than medium sized palm species, but the small palms were still the least represented with three species (Table 1, Fig. 3). Terrace forest had equal numbers of tall and medium sized palm species. Six small palms were found in the terrace forest, which represented a little fewer species than the two other growth forms (Table 1, Fig. 3).

\section{Discussion}

The 42 species and 18 genera found in our study of the Madre de Dios palm communities represent around a third of the species and a little more than half the genera reported for Peru (Kahn \& Moussa 1994). We went through the list of species compiled by Henderson $(1995,2000)$ and found 55 species in 19 genera registered for the entire Madre de Dios region (Table 3). Twelve species on these lists were not recorded by us, but we found Geonoma laxiflora, which had not been registered in Madre de Dios. Compared to the size of our study area and limited number of habitats investigated, the detected number of species and genera seems high. With additional transects, especially in terrace and premontane hill forests, we might have discovered several more species. Balslev et al. (2012) made 65 transects in five different habitats in adjacent Bolivia and found the same number of genera but fewer species than we found in the Madre de Dios region. Still, there are more diverse places than the Madre de Dios region in Peru. For instance, surveys in the upper Ucayali river valley in northeastern Amazonian Peru recorded 56 palms species in only 35 transects covering the same four habitats (Balslev et al. 2010).

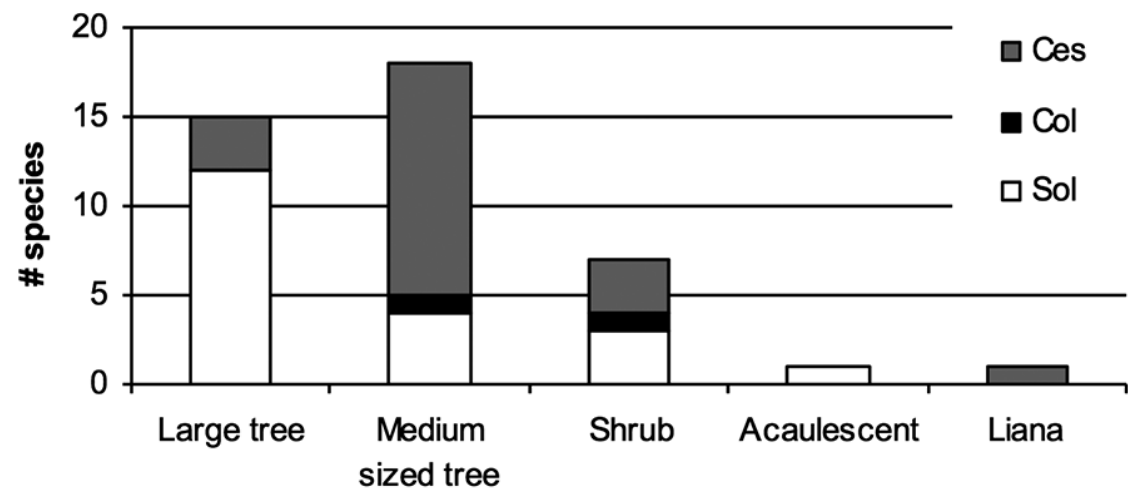

Figure 4. Relative abundance of growth forms of palms found in the forests of Madre de Dios region in Peru, and indication of the relative proportion of solitary (Sol), cespitose (Ces) and colonial species (Col) in each of the growth forms. 
Table 2. Data showing the location, altitude and habitat of each transect.

\begin{tabular}{|c|c|c|c|c|c|c|}
\hline Transect \# HB & Province & Locality & Habitat & Altitude (m) & $x$ & $\mathrm{Y}$ \\
\hline 406 & Madre de Dios & Inka Terra & Floodplain & 195 & 494634 & 8614309 \\
\hline 407 & Madre de Dios & Inka Terra & Floodplain & 193 & 494913 & 8615361 \\
\hline 408 & Madre de Dios & Reserva Ecologica Taricaya & Floodplain & 185 & 500878 & 8615674 \\
\hline 409 & Madre de Dios & Gamitana \& Agua Negra \& Lo Boyo & Floodplain & 186 & 501073 & 8619115 \\
\hline 410 & Madre de Dios & Gamitana \& Agua Negra \& Lo Boyo & Floodplain & 192 & 502682 & 8618815 \\
\hline 411 & Madre de Dios & Inka Terra & Floodplain & 191 & 493738 & 8614117 \\
\hline 412 & Madre de Dios & Palma Real & Terra firme & 211 & 518612 & 8616180 \\
\hline 413 & Madre de Dios & Palma Real & Floodplain & 188 & 516343 & 8617324 \\
\hline 414 & Madre de Dios & Palma Real & Terra firme & 200 & 515501 & 8613726 \\
\hline 415 & Madre de Dios & Palma Real & Floodplain & 182 & 520269 & 8618061 \\
\hline 416 & Madre de Dios & Palma Real & Floodplain & 179 & 520932 & 8617035 \\
\hline 417 & Madre de Dios & Palma Real & Terra firme & 194 & 526057 & 8617640 \\
\hline 418 & Madre de Dios & Palma Real & Terra firme & 205 & 512808 & 8607916 \\
\hline 419 & Madre de Dios & Palma Real & Terra firme & 196 & 513510 & 8611258 \\
\hline 420 & Madre de Dios & Palma Real & Terra firme & 212 & 514977 & 8621644 \\
\hline 421 & Madre de Dios & Palma Real & Terra firme & 205 & 520874 & 8616083 \\
\hline 422 & Madre de Dios & Palma Real & Terra firme & 210 & 523337 & 8615042 \\
\hline 423 & Tahuamanu & Iñapari & Terra firme & 300 & 441497 & 8779197 \\
\hline 424 & Tahuamanu & Iñapari & Terra firme & 315 & 441796 & 8780385 \\
\hline 425 & Tahuamanu & Iñapari & Terra firme & 300 & 437603 & 8782080 \\
\hline 426 & Tahuamanu & Iñapari & Terra firme & 308 & 441081 & 8784023 \\
\hline 427 & Tahuamanu & Iñapari & Terra firme & 303 & 438395 & 8778975 \\
\hline 428 & Tahuamanu & Iñapari & Terra firme & 324 & 436938 & 8777494 \\
\hline 429 & Tahuamanu & Iñapari & Terra firme & 309 & 438435 & 8771642 \\
\hline 430 & Tahuamanu & Iñapari & Terra firme & 310 & 438634 & 8775123 \\
\hline 431 & Tahuamanu & Iñapari & Terra firme & 308 & 439651 & 8766660 \\
\hline 432 & Tahuamanu & Iñapari & Terra firme & 339 & 438197 & 8762006 \\
\hline 433 & Tahuamanu & Iñapari & Terra firme & 322 & 439937 & 8756840 \\
\hline 434 & Tahuamanu & Iñapari & Terra firme & 332 & 444088 & 8751590 \\
\hline 435 & Madre de Dios & Sector Fitzcarrald & Terra firme & 238 & 463878 & 8601416 \\
\hline 436 & Madre de Dios & Las Mercedes & Terra firme & 212 & 450245 & 8596366 \\
\hline 437 & Tambopata & San Juan & Terra firme & 249 & 426200 & 8578113 \\
\hline 438 & Tambopata & Interoceanico sur nr 3 & Terra firme & 245 & 416608 & 8574894 \\
\hline 439 & Madre de Dios & Interoceanico sur $\mathrm{nr} 1$ & Terra firme & 260 & 485400 & 8621821 \\
\hline 440 & Madre de Dios & Bello Horizonte & Terra firme & 236 & 490741 & 8621281 \\
\hline 441 & Madre de Dios & Infierno & Terra firme & 223 & 474833 & 8593635 \\
\hline 442 & Madre de Dios & Santa Rosa & Terra firme & 440 & 355099 & 8570951 \\
\hline 443 & Madre de Dios & Santa Rosa & Terrace & 300 & 357699 & 8574112 \\
\hline 444 & Madre de Dios & Santa Rosa & Terrace & 282 & 359094 & 8576785 \\
\hline 445 & Madre de Dios & Santa Rosa & Terrace & 281 & 360863 & 8578796 \\
\hline 446 & Madre de Dios & Santa Rosa & Premontane & 342 & 362948 & 8568652 \\
\hline 447 & Madre de Dios & Santa Rosa & Terra firme & 300 & 363269 & 8570698 \\
\hline 448 & Madre de Dios & Santa Rosa & Terra firme & 297 & 361176 & 8572467 \\
\hline 449 & Madre de Dios & Santa Rosa & Premontane & 385 & 359790 & 8569888 \\
\hline 450 & Madre de Dios & Santa Rosa & Terrace & 273 & 371614 & 8574717 \\
\hline 451 & Madre de Dios & Santa Rosa & Terrace & 267 & 370760 & 8580996 \\
\hline 452 & Madre de Dios & Santa Rosa & Terrace & 343 & 353317 & 8559110 \\
\hline 453 & Madre de Dios & Santa Rosa & Premontane & 448 & 355321 & 8558571 \\
\hline 454 & Madre de Dios & Reservar Ecologica Taricaya & Floodplain & 187 & 503400 & 8615508 \\
\hline 455 & Madre de Dios & Reservar Ecologica Taricaya & Floodplain & 230 & 502158 & 8615482 \\
\hline 456 & Madre de Dios & Reservar Ecologica Taricaya & Floodplain & 172 & 503332 & 8615482 \\
\hline 457 & Madre de Dios & Reservar Ecologica Taricaya & Floodplain & 211 & 500825 & 8614031 \\
\hline 458 & Madre de Dios & Reservar Ecologica Taricaya & Floodplain & 186 & 502567 & 8615973 \\
\hline 459 & Madre de Dios & Reservar Ecologica Taricaya & Floodplain & 191 & 501710 & 8616056 \\
\hline
\end{tabular}


Table 3. Species registered in the Madre de Dios region by Henderson (1995, 2000). The twelve species not found in this study are highlighted in bold.

\begin{tabular}{|c|c|c|}
\hline Chelyocarpus ulei & Attalea butyracea & Bactris simplifrons \\
\hline Mauritia flexuosa & Attalea maripa & Bactris sphaerocarpa \\
\hline Chamaedorea angustisecta & Attalea phalerata & Astrocaryum murumuru murumuru (gratum/ulei) \\
\hline Chamaedorea pauciflora & Attalea tessmannii & Astrocaryum huaimi (gratum/ulei) \\
\hline Chamaedorea pinnatifrons & Aiphanes aculeata (A. horrida) & Astrocaryum murumuru javarense (gratum/ulei) \\
\hline Wendlandiella gracilis & Aiphanes weberbaueri & Pholidostachys synanthera \\
\hline Iriartea stenocarpa & Bactris acanthocarpa & Geonoma brevispatha \\
\hline Iriartea deltoidea & Bactris brongniartii & Geonoma brongniartii \\
\hline Socratea exorrhiza & Bactris chaveziae & Geonoma camana \\
\hline Socratea salazarii & Bactris concinna & Geonoma deversa \\
\hline Wettinia augusta & Bactris gasipaes chichagui & Geonoma interrupta \\
\hline Euterpe precatoria & Bactris hirta spruceana & Geonoma macrostachys acaulis \\
\hline Oenocarpus bataua & Bactris macana & Geonoma macrostachys macrostachys \\
\hline Oenocarpus balickii & Bactris maraja juruensis & Geonoma maxima chelidonura \\
\hline Oenocarpus mapora & Bactris maraja maraja & Geonoma stricta piscicauda \\
\hline Hyospathe elegans & Bactris maraja trichospatha & Geonoma stricta trailii \\
\hline Syagrus sancona & Bactris martiana & Geonoma triglochin \\
\hline Desmoncus mitis & Bactris riparia & Phytelephas macrocarpa \\
\hline Desmoncus polyacanthos & & \\
\hline
\end{tabular}

The Madre de Dios forests had densities of 1709 - 3245 (average 2755) palms/hectare which overlaps with densities recorded in Ucayali (1460 - 6756 palms/hectare, average 3512; Balslev et al. 2010) and that are similar to values recorded in the Colombian Amazon (2900 - 3737 individuals/hectare, average 3301; Balslev unpublished data).

The range extension of 40 - 320 kilometers for seven species testifies to the patchy nature of the present state of knowledge of Amazon palms. In a study in the upper Ucayali river valley one third of all the palms encountered were found $150-400$ kilometers beyond their previously known ranges (Balslev et al. 2010).

We identified four forest habitats in our study area: terra firme, floodplain, terrace and premontane hills. This is similar to the study in Ucayali (Balslev et al. 2010) where the same four habitats were encountered, where the only difference was that premontane hills were called Andean hills. Thus, for the present study, we tried to standardize the classification in order to make comparisons possible.

The terra firme forest in our study recorded the second highest density of palms, and the greatest species richness. In contrast, Balslev et al. (2010) mention the terra firme forest in the Ucayali study as a forest with low density and diversity of palms, which may be due to the difference in sampling intensity carried out between the two studies since the Ucayali study included only a single transect in terra firme.

In general, floodplain forests have been shown to be not as diverse as the other habitats (Balslev et al. 2011). If the sampling effort in terrace and premontane forest had been a little higher we might have seen a few more species on the list.
Geonoma deversa and G. occidentalis were recorded as the two most abundant species. This differs greatly from other palm community studies in Peru (Kahn \& Mejia 1990, Balslev et al. 2010, Kahn \& Moussa 1994). Geonoma occidentalis (previously known as $G$. brevispatha) is not present in any of these studies. The distribution maps in Henderson (2011) show that its distribution is limited to the southern part of the Madre de Dios region in Peru and large parts of Bolivia and Brazil. A study in Bolivia showed high density of Geonoma occidentalis as well (Balslev et al. 2012), so it would seem that Geonoma occidentalis dominates these forests. Geonoma deversa is widespread throughout the Amazon basin (Henderson 1995), but seems to be particularly abundant in the Madre de Dios region compared to other regions (Balslev et al. 2010, Kahn \& Mejia 1990). We also found species like Euterpe precatoria, Attalea phalerata, Iriartea deltoidea, Astrocaryum gratum and Astrocaryum ulei among the abundant species. The abundance of these large palm species is not because they totally dominate the habitats in which they are found. It seem that they have a high environmental adaptability, being able to grow in all habitats with small variations in density. It has also been demonstrated, that widespread palms tend to be tall and habitat generalists (Roukolainen $\&$ Vormisto 2000). Height maybe be associated with better dispersal of seeds, which contributes to a wider range. This agrees with the results in our study, where 14 species are found in all habitats and half of those are tall palm species.

As was to be expected for a high diversity area, we found a long tail of rare species (Zimmerman et al. 2008). Our study helps to clarify the conservation status of palms in the Madre de Dios region. A species like Geonoma camana is listed by Kahn and Moussa (1994) as insufficiently known in situ for the conservation status to be defined. In our study it would be listed 
as rare, since it was found in low densities in all habitats except floodplain. Another palm whose conservation status could be changed (from rare to not threatened) is Astrocaryum huicungo, which is now called $A$. ulei or A. gratum in our region (Kahn \& Millán 2009, Kahn \& Millan 2013). Astrocaryum ulei and $A$. gratum were both abundant species, but interestingly enough they never occurred together. Astrocaryum ulei was found north of the Madre de Dios river while A. gratum was recorded to the south of it. It appears that the river functions as an effective dispersal barrier (Kahn et al. 2011).

Of the 42 species found, approximately 50\% were solitary, $45 \%$ cespitose and 5\% were colonial. Balslev and collaborators (2011) collected data from a large number of palm community studies all over the Amazon and Central America and found an average of $33 \%$ solitary and $66 \%$ cespitose species. Compared to that, it seem that solitary species are better represented in the Madre de Dios region respectively.

\section{Conclusion}

We found 42 species of palms in the palm communities in Peru's Madre de Dios region. Higher local species richness has been found elsewhere, but the Madre de Dios region is definitely one of the world's "hot spots" for palm diversity. With 38 different species and 2968 individuals per hectare the terra firme forest had the richest palm flora. The same pattern has been shown in other locations where terra firme communities are known for their extremely high local species richness (Balslev et al. 2011, Kahn \& de Granville 1992). The palm communities of floodplain, terrace and premontane hill had similar species richness, but terrace forest had much lower abundance of palms. This is opposite to what has been found in the upper Ucayali river valley (Balslev et al. 2010), where terrace forest had by far the highest abundance of palms. The different results of the two studies show how important it is to know an area before deciding how to manage it. For example when exploiting palm species in terrace forests, the lower density in Madre de Dios should be taken into account so that the pressure on the forest is lowered compared to Ucayali. Bernal et al. (2011) discussed the management for 96 species of palms in South America and showed the necessity for stopping the custom of destructive harvest and assessing production of exploited areas.

In our study area the palms occupied all strata of their habitats. Palms were not as species rich or as abundant in the understory as they were in the mid-canopy and in the top of the canopy. The seven most abundant species were all found in the mid- and top canopy.

\section{Acknowledgements}

This work was supported by the Danish Council for Independent Research - Natural Sciences [grant\#4181-00158 to HB] and the European Community [FP7 grant \#212631 to HB]. We would also like to thank the people of Taricaya lodge for providing facilities and volunteers necessary to complete several transects in that area. A special thanks to Fernando Rosemberg and Stuart Timson for sharing their knowledge of the forest and the palms in forest at the beginning of the project.

\section{Literature cited}

Baker, W.J. \& J. Dransfield. 2016. Beyond Genera palmarum: Progress and prospects in palm systematics. Botanical Journal of the Linnean Society Early online. DOI: http://dx.doi.org/ 10.1111/boj.12401

Balslev H. 2011. Palm harvest impacts in north-western South America. The Botanical Review 77: 370-380. DOI: http:// dx.doi.org/10.1007/s12229-011-9083-y

Balslev H., W. Eiserhardt, T. Kristiansen \& D. Pedersen. 2010. Palms and palm communities in the upper Ucayali river valley - a little known region in the Amazon basin. Palms - Journal of the International Palm Society 54 (2): 57-72.

Balslev H., F. Kahn, B. Millan, J.-C. Svenning, F. Borchsenius, T. Kristiansen, D. Pedersen \& W. Eiserhardt. 2011. Species diversity and growth forms in tropical American palm communities. The Botanical Review 77 (4): 381-425. DOI: http://dx.doi.org/10.1007/s12229-011-9084-x

Balslev H., M.J. Macía \& H. Navarrete. Eds. 2015. Cosecha de palmas en el noroeste de Suramérica: Bases científicas para su manejo y conservacíon. Quito: Pontificia Universidad Católica del Ecuador.

Balslev H., Z. Pérez Durán, D. Pedersen, W. L. Eiserhardt, A. Sanjinéz \& N. Paniagua-Zambrana. 2012. Subandean and adjacent lowland palm communities in Bolivia. Ecología en Bolivia 47 (1): 7-36.

Bernal R., C. Torres, N. García, C. Isaza, J. Navarro, M.I. Vallejo, G. Galeano \& H. Balslev. 2011. Palm management in South America. The Botanical Review. 77 (4): 607-646. DOI: http://dx.doi.org/10.1007/s12229-011-9088-6

Bjorholm S., J.-C. Svenning, F. Skov \& H. Balslev. 2005. Environmental and spatial controls of palm (Arecaceae) species richness across the Americas. Global Ecology and Biogeography 14: 423-429. DOI: http://dx.doi.org/10.1111/j.1466822x.2005.00167.x

Brokamp G., N. Valderrama, M. Mittelbach, C.A. Grandez R., A.S. Barfod \& M. Weigend. 2011. Trade in palm products in north-western South America. The Botanical Review 77: 571-606. DOI: http://dx.doi.org/10.1007/s12229-011$9087-7$

Cochrane T.T. \& T.A. Cochrane. 2011. Amazon Forest and Savanna Lands: A guide to the climates, vegetation, landscapes, and soils of central tropical South America. Scotts Valley, CA: CreateSpace.

Dransfield J., N.W. Uhl, C.B. Asmussen, W.J. Baker, M.M. Harley \& C.E. Lewis. 2008. Genera Palmarum: The Evolution and Classification of Palms. London: Royal Botanic Gardens, Kew, UK.

Galeano G. \& R. Bernal. 2010. Palmas de Colombia - Guía de campo. Bogotá: Universidad Nacional de Colombia.

Henderson A. 1995. The Palms of the Amazon. Oxford and New York: Oxford University Press.

Henderson, A. 2000. Bactris (Palmae). Flora Neotropica Monograph 79: $1-181$.

Henderson, A. 2011. A revision of Geonoma (Arecaceae). Phytotaxon 17: 1-271.

Henderson, A., G. Galeano \& R. Bernal. 1995. Field Guide to the Palms of the Americas. Princeton, New Jersey: Princeton University Press.

Kahn F. 1988. Ecology and economically important palms in Peruvian Amazonia. Economic Botany 6: 42-49.

Kahn F. \& J.J. de Granville. 1992. Palms in the forest ecosystems of Amazonia. Heidelberg: Springer.

Kahn F. \& K. Mejia. 1990. Palm communities in wetland forest ecosystems of Peruvian Amazonia. Forest Ecology and Management 33/44: 169-179. DOI: http://dx.doi. org/10.1016/0378-1127(90)90191-D

Kahn F. \& B. Millán. 2009. Astrocaryum ulei (Arecaceae) newly discovered in Peru. Rev. Peru. Biol. 16 (2): 161-164. DOI: http://dx.doi.org/10.15381/rpb.v16i2.199

Kahn F. \& B. Millán. 2013. The Huicungo Palms. Lima: UNMSMIRD, 173 pp.

Kahn F. \& F. Moussa. 1994. Diversity and conservation status of Peruvian palms. Biodiversity and Conservation 3: 227-241. DOI: http://dx.doi.org/10.1007/BF00055940 
Kahn F., Millán B, Pintaud J.-C., Machahua M. 2011. New data on the distribution of the palm species of the section Huicungo (Astrocaryum, Arecaceae) in Peru. Rev. Peru Biol. (18) 3: 279-282. DOI: http://dx.doi.org/10.15381/rpb.v18i3.438

Kinnaird M.F. 1992. Competition for a forest palm: Use of Phoenix reclinata by human and nonhuman primates. Conservation Biology 6: 101-107. DOI: http://dx.doi.org/10.1046/ j.1523-1739.1992.610101.x

Moraes M. 2004. Flora de Palmeras de Bolivia. La Paz: Plural Editores.

Peres C.A. 1994. Composition, density, and fruiting phenology of arborescent palms in an Amazonian terra firme forest. Biotropica 26 (3): 285-294.
Roukolainen K. \& J. Vormisto. 2000. The most wide spread Amazonian palms tend to be tall and habitat generalists. Basic and Applied Ecology 1: 97-108. DOI: http://dx.doi. org/10.1078/1439-1791-00020

Sanín M.J. \& G. Galeano. 2011. A revision of the Andean wax palms, Ceroxylon (Arecaceae). Phytotaxa 34: 1-64.

Salo J., R. Kalliola, I. Häkkinen, Y. Mäkinen, P. Niemelä, M. Puhakka \& P.D. Coley. 1986. River dynamics and the diversity of Amazon lowland forest. Nature 322: 254-258. DOI: http:// dx.doi.org/10.1038/322254a0

Zimmerman J.K., Thompson, J. \& N. Brokaw. 2008. Large tropical forest dynamics plots: Testing explanations for maintenance of species diversity. Chapter 7 In: W.P. Carson and S.A. Schnitzer eds. Tropical Forest Community Ecology. Oxford: Wiley-Blackwell. Pp. 98-117. 